\title{
Article
}

\section{Tar spot fungi from Thailand}

\section{Tamakaew N ${ }^{1}$, Maharachchikumbura $\mathrm{SSN}^{2}$, Hyde $\mathrm{KD}^{3,4}$ and Cheewangkoon $\mathbf{R}^{1^{*}}$}

${ }^{1}$ Entomology and Plant Pathology Department, Faculty of Agriculture, Chiang Mai University

${ }^{2}$ Department of Crop Sciences, College of Agricultural and Marine Sciences, Sultan Qaboos University, P.O. Box 8, 123, Al Khoud, Oman.

${ }^{3}$ Center of Excellence in Fungal Research, Mae Fah Luang University, Chiang Rai 57100, Thailand

${ }^{4}$ World Agroforestry Centre, East and Central Asia, 132 Lanhei Road, Kunming 650201, China

Tamakaew N, Maharachchikumbura SSN, Hyde KD, Cheewangkoon R. 2017 - Tar spot fungi from Thailand. Mycosphere 8(8), 1054-1058, Doi 10.5943/mycosphere/8/8/6

\begin{abstract}
Phyllachora species are responsible for leaf tar spot disease in a wide range of hosts, worldwide. We are studying the phyllachoraceous taxa in northern Thailand. In this paper, we report on two taxa collected from symptomatic graminicolous leaves collected during 2015-2016. The taxa are shown to be novel based on morphological and sequence data and introduced here as Phyllachora thysanolaenae collected from Thysanolaena maxima and Phyllachora vetiveriana from Chysopogon zizanioides. Descriptions, illustrations and molecular data are provided for the new species which are discussed with comparable taxa.
\end{abstract}

Key words - Phyllachora - tar spot

\section{Introduction}

Species of Phyllachoraceae are most obligate parasites, producing black "tar spots" on leaves and occasionally stems and fruits of a variety of host plant families with most taxa presumed to be host-specific (Cannon 1997). This family comprises more than a thousand species worldwide, with Phyllachora as the type genus (Parbery 1978, Kirk et. al. 2008). The genus Phyllachora infects more than 1000 host species, and is often found associated with Gramineae, Leguminae, Moraceae and myrtaceous hosts (Cannon 1991, Cannon \& Hyde 1999, Pearce \& Hyde 2006, Maharachchikumbura et al. 2015, 2016). Phyllachora has been reported to be minor plant pathogens, that rarely kill the host tissues (Mehrotra \& Aneja 1990, Cannon 1991), but their longevity on host tissue, may attract or provide pathways for secondary infection by other, more severe pathogenic organisms (Cannon 1991, Hock et al. 1992, Parbery 1996). Nonetheless, information on Phyllachora species in Thailand is generally lacking, and presently only seven species have been reported, namely Phyllachora bambusae, P. coicis, $P$. cynodontis, $P$. digitariae, P. graminis, P. pterocarpi and P. repens (Giatgong 1980, Nuangpai et al. 1984, Lenne 1990, Athipunyakom \& Likhitekaraj 2009).

There have been few recent studies on Phyllachora, mainly because the taxa are biotrophic and will not grow in culture and therefore it is hard to obtain sequence data from fresh collections. Sequence data of nrSSU, nrLSU and ITS showed that Phyllachorales is polyphyletic (WanderleiSilva et. al. 2003, Habibi et. al. 2015). Mardones et al. (2017) introduced a new family 
Telimenaceae in Phyllachorales, alongside Phyllachoraceae and Phaeochoraceae based on ribosomal LSU, SSU, ITS, and protein coding RPB2 and TEF1 genes.

In this paper, we introduce two new species of Phyllachora discovered during surveys of tar spot disease in northern Thailand from 2015-2016. Descriptions, illustrations and sequence data are provided for the new species which are discussed with comparable taxa.

\section{Materials \& Methods}

Survey of plants with tar spot symptoms caused by fungi was carried out from May 2015 through to August 2016. The specimens were collected in Chiang Mai Province, Thailand. Measurements and descriptions of sections of the ascomata, asci and ascospores were carried out by immersing ascomata in water or in Shear's reagent. Unless otherwise stated, all photographs and measurements were made from material mounted in water and 95\% lactic acid. Slide were viewed under a Nikon SMZ745T stereo microscope $(\times 4.5)$ and ZEISS Scope A1 microscope $(\times 40-100)$ where diagnostic morphological features were recorded photomicrographs and measurements were taken.

\section{DNA extraction, PCR amplification and sequencing}

Total genomic DNA was extracted directly from DNA extraction kit (E.Z.N.A. Forensic DNA Kit), following the protocols in the manufacturer's instructions (Habibi et. al. 2015). The DNA amplification was obtained by polymerase chain reaction (PCR). nrSSU, nrLSU and ITS region were amplified by the PCR primes reaction mixture and the thermal cycle program applied by (Habibi et. al. 2015). Sequences generated in this study were blasted to search for closet taxa in GenBank database (www.ncbi.nlm.nih.gov/blast/).

\section{Results}

Phyllachora thysanolaenae Tamakaew, Cheew \& K.D. Hyde, sp. nov.

MycoBank number: MB821879; Facesoffungi number: FoF 03510; GenBank- SSU: MF272147, Fig 1

Etymology - Named after its host genus, Thysanolaena.

Holotype - MFLU 16-2071

Causing tar spot on living host leaves. Tar spots $0.3-2 \times 0.2-2 \mathrm{~mm}$ on upper leaves surface, black punctiform spots, ovoid, shiny, with the raised glossy black clypeus covering the ascomata, chlorotic of reddish yellow discoloured host tissue. Sexual morph: Stromata uni-multiloculate, 0.3-0.4 $\mu \mathrm{m}$ high, 0.6-1.5 mm diam., ovoid, on the upper leaves surface, the stroma immersed with the upper wall of the ascoma, black thick-walled completely occluded by melanins. Ascomata, perithecial 175-(205-250) $\mu \mathrm{m}$ high, 270-(300-370)-410 $\mu \mathrm{m}$ diam., flask to bowl shape, single or forming in group of $1-4$, globose, the ostiole inconspicuous, not or only weakly papillate. Peridium composed of thin, dark brown. Paraphyses longer than mature asci, filiform, unbranched, septate, not construct at septate. Asci 13-18 × (100-114)-126 $\mu \mathrm{m}$ ellipsoid to obclavate, fairly shortstalked, very thin-walled, the apex obtuse to rounded without visible apical structures. Ascospores 4-5 $\times 21-24 \mu \mathrm{m}$ arranged irregularly, cylindrical - fusiform, occasionally very slightly curved, guttulate, thin-walled, hyaline, surrounded by mucilaginous sheath. Asexual morph: Not observed.

Material examined - THAILAND, Chiang Mai Province, Chom Thong District, Ban Mae Klang Luang, on living leaves of Thysanolaena maxima (Poaceae), 5 March 2016, N. Tamakaew (MFLU 16-2071, holotype).

Notes - The collection was identified as belonging to Phyllachora on the basis of external symptomatology and morphological characteristics. Of the Phyllachora species known from Thysanolaena maxima (Parbery \& Langdon 1964), P. thysanolaenae is distinct from other species in having smaller ascospores. The closest hits using the SSU sequence had the highest similarity to Phyllachora graminis isolate UME 31349 (GenBank AF064051, Identities = 962/1039 (93 \%)) 

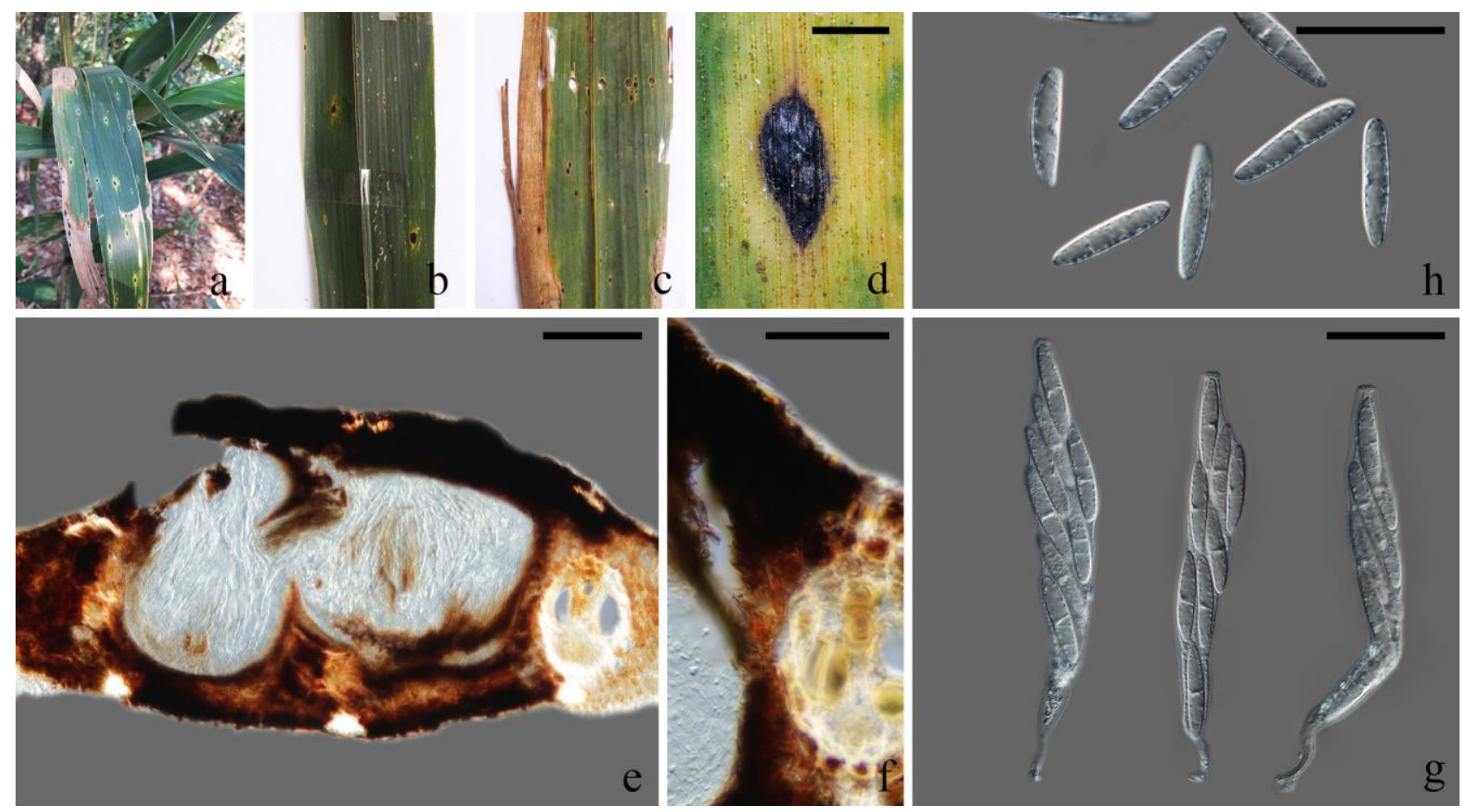

Fig. 1 Phyllachora thysanolaenae on Thysanolaena maxima leaves (holotype, MFLU 16-2071). a, b. Tar spots on upper surface leaves. c. Tar spots on lower surface leaf. d. Close up tar spot lesion. e. Vertical section through tar spot illustrating central ostiole, peridium and position in host tissues. f. Vertical section through peridium. g. Ascospores. h. Asci. Scale bars: $d=5 \mathrm{~mm}, \mathrm{e}=500 \mu \mathrm{m}, \mathrm{f}=$ $30 \mu \mathrm{m}, \mathrm{h}=25 \mu \mathrm{m}, \mathrm{g}=20 \mu \mathrm{m}$.

Phyllachora chrysopogonicola Tamakaew, Cheew \& Hyde K.D. sp. nov.

MycoBank number: MB821880; Facesoffungi number: FoF 03511; GenBank number: LSU: MF372146, ITS: MF372145, Fig 2

Etymology - Named after the host genus from which it was collected, Chrysopogon.

Holotype - MFLU 16-2096

Causing tar spot on living leaves of Chrysopogon zizanioides, Tar spots $0.2-0.5 \times 0.1-0.5 \mathrm{~mm}$ on upper leaves surface, black punctiform spots, globose to irregular, shiny, low to moderately domed, with the raised glossy black clypeus covering the ascomata. Sexual morph: Stromata unimultiloculate, 137-(167-212)-250 $\mu \mathrm{m}$ high, 155-(170-210)-245 $\mu \mathrm{m}$ diam., globose to irregular, on the upper leaves surface, the stroma immersed with the upper wall of the ascoma, black thickwalled completely occluded by melanins. Ascomata, perithecial 115-(145-192)-245 $\mu \mathrm{m}$ high, 132-(182-215) $\mu \mathrm{m}$ diam., flask-shaped, bowl-shaped, solitary or forming groups of 1-2, globose, the ostiole inconspicuous, not or only weakly papillate. Peridium composed of thin, dark brown. Paraphyses filiform, unbranded, septate. Asci, 12.5-15×70-122 $\mu \mathrm{m}$ ascospores increase in size and become biseriate. Ascospores $6-8 \times 20-(26-30) \mu \mathrm{m}$ unicellular to papillate to turbinate, clavate, smooth, hyaline, surrounded by mucilaginous sheath. Asexual morph: Not observed.

Material examined - THAILAND, Chiang Mai Province, Mae Rim District, Queen Sirikit Botanic Garden, on living leaves of Chrysopogon zizanioides (Poaceae), 11 November 2015, N. Tamakaew (MFLU 16-2096, holotype).

Notes - Phyllachora chrysopogonicola has characters typical of Phyllachora in producing black leaf spots, with immersed thin-walled, ostiolate ascomata, and aseptate ascospores (Pearce \& Hyde, 2006). Four species have been recorded on Chysopogon spp. namely P. anthistiriae (Ahmad, 1969), P. ischaemi (Williams \& Liu 1976), P. fallax (Parbery 1967) and P. graminis (Lenne 1990). Compared with morphological characteristics of those known species from Chysopogon spp., $P$. chrysopogonicola is distinguished by having obviously clavate or tear-shaped ascospores. The closest hits using the ITS sequence had the highest similarity to Phyllachorales sp. L0002 
$($ GenBank KM108581, Identities $=456 / 558(82 \%))$, and Phyllachorales sp. L0001 (GenBank KM108580, Identities $=456 / 559(82 \%))$. The closest hits using the LSU sequence had the highest similarity to Camarops ustulinoides SMH1988 (GenBank AY346267, Identities = 788/863 (91 \%)), and $C$. polysperma Hanson2006-747 (GenBank JN673030, Identities = 785/863 (91\%)).
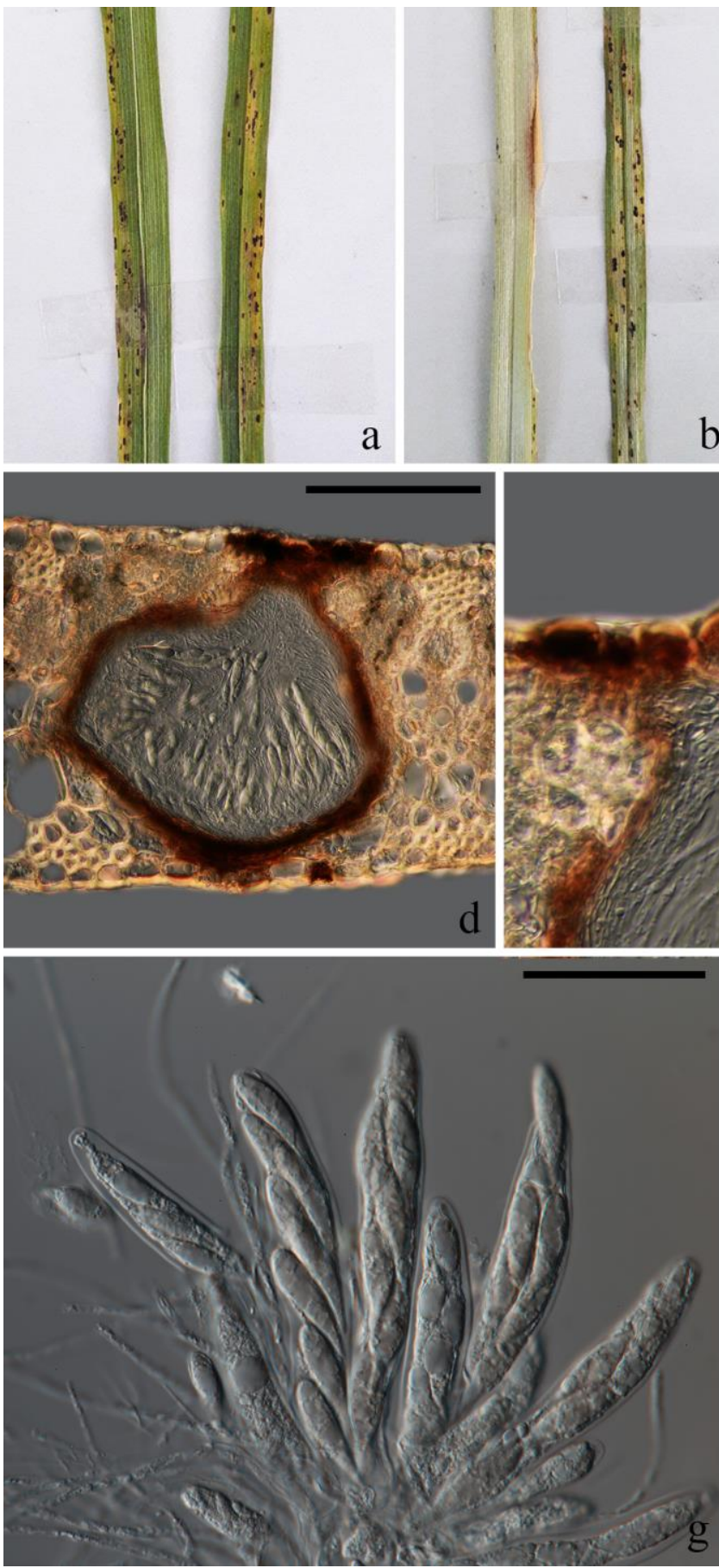
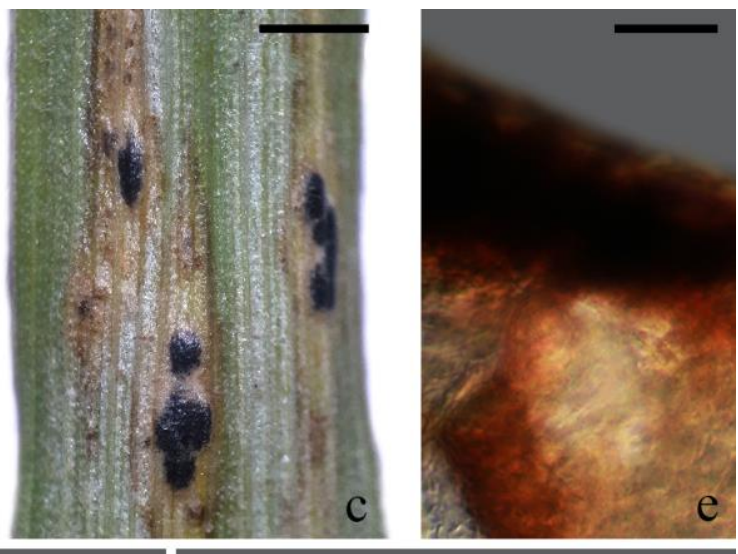

b
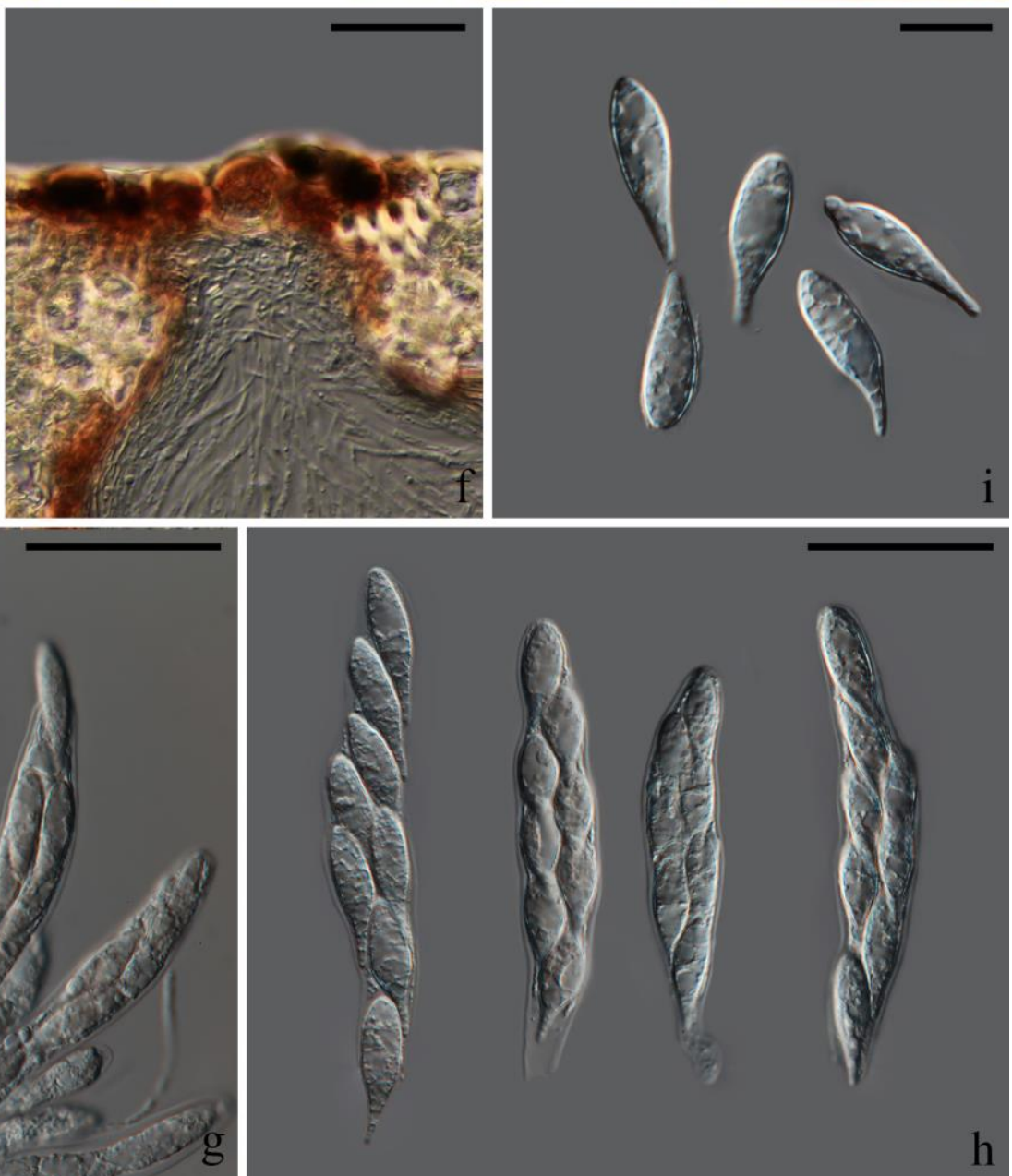

Fig. 2 Phyllachora chrysopogonii on Chrysopogon zizanioides leaves (holotype, MFLU 16-2096,). a, b. Tar spots on upper surface. c. Close up of tar spots on leaf. d. Vertical section through tar spot illustrating central ostiole, peridium and position in host tissues. e. Vertical section through peridium. f. Vertical section through ostiolar canal. g. Asci and paraphyses h. Asci, i. Ascospores. Scale bars: $\mathrm{c}=5 \mathrm{~mm}, \mathrm{~d}=100 \mu \mathrm{m}, \mathrm{e}=30 \mu \mathrm{m}, \mathrm{f}=20 \mu \mathrm{m}, \mathrm{g}=30 \mu \mathrm{m} \mathrm{h} .=30 \mu \mathrm{m}, \mathrm{I}=20 \mu \mathrm{m}$. 


\section{Acknowledgements}

This work was supported by Thailand Research Fund (MRG5580163), Graduate School of Chiang Mai University and Mushroom Research Foundation.

\section{References}

Ahmad S. 1969 - Fungi of West Pakistan. Biological Society of Pakistan Monograph. 5 (Sup.1): $1-110$.

Athipunyakom P, Likhitekaraj S. 2009 - Taxonomy on Plant Pathogenic Fungi Class Ascomycetes. Plant Pathology Research Group, Plant Protection Research and Development Office, Department of Agriculture, Bangkok.

Cannon PF. 1991 - A Revision of Phyllachora and some similar genera on the family Leguminosae. Mycological Papers 163, 1-302.

Cannon PF. 1997 - Diversity of Phyllachoraceae with special reference to the tropics. In: Biodiversity of tropical microfungi. Hong Kong University Press, Hong Kong, 255-278.

Hyde KD, Cannon PF. 1999. Fungi causing tar spots on palms. Mycological Paper 175, 1-114.

Kirk PM, Cannon PF, Minter DW, Stalpers JA. 2008 - Dictionary of the fungi. Cromwell Press, Trowbridge.

Habibi A, Banihashemi Z, Mostowfizadeh-Ghalamfarsa R. 2015 - Phylogenetic analysis of Polystigma and its relationship to Phyllachorales. Phytopathologia Mediterranea 54, 45-54.

Hock J, Dittrich U, Renfro BL, Kranz. 1992 - Sequential development of pathogens in the maize tarspot disease complex. Mycopathologia 117, 157-161.

Lenne JM. 1990 - World list of fungal diseases of tropical pasture species. Phytopathological Paper $31,1-162$.

Maharachchikumbura SSN, Hyde KD, Jones EBG, McKenzie EHC et al. 2015 - Towards a natural classification and backbone tree for Sordariomycetes. Fungal Diversity 72, 199-301

Maharachchikumbura SSN, Hyde KD, Jones EBG, McKenzie EHC et al. 2016 - Families of Sordariomycetes. Fungal Diversity 79, 1-317.

Mardones M, Trampe-Jaschik T, Oster S, Elliott M et al. 2017 - Phylogeny of the order Phyllachorales (Ascomycota, Sordariomycetes): among and within order relationships based on five molecular loci. Persoonia 39, 74-90.

Mehrotra SR, Aneja KR. 1990 - An introduction to mycology. Wiley Eastern Limited. New Delhi.

Nuangpai S, Aunchairsungkad D, Chainngkun A, Jamkajang V. 1984 - A study of tar spot of Coix lachrymal-jobi L.in Thailand. Department of Agriculture. Bangkok.

Parbery DG, Langdon RFN. 1964 - Studies on graminicolous species of Phyllachora FCKL. IV. evaluation of the criteria of species. Australian Journal Botany 12: 265-281.

Parbery DG. 1967 - Studies on graminicolous species of Phyllachora Nke. in Fckl. V. A taxonomic monograph. Australian Journal Botany 15, 271-375.

Parbery DG. 1996 - Trophism and ecology of fungi associated with plants. Biological Review of the Cambridge Philosophical Society 71, 474-521.

Pearce CA, Hyde KD. 2006 - Phyllachoraceae of Australia. Fungal Diversity Research Series 17, $1-308$.

Williams TH, Liu PSW. 1976 - A host list of plant diseases in Sabah, Malaysia. Phytopathological Paper 19, 1-67.

Wanderlei-Silva D, Ramalho Neto E, Hanlin R. 2003 - Molecular systematics of the Phyllachorales (ascomycota, fungi) based on $18 \mathrm{~S}$ ribosomal DNA sequences. Brazilian Archives of Biology and Technology 46, 315-322. 